\title{
KONTRIBUSI KONTRAKTOR TERHADAP PENGURANGAN RESIKO KEGAGALAN BANGUNAN AKIBAT GEMPA DI KOTA PADANG
}

\author{
Resi Elfitri ${ }^{1}$, Akhmad Suraji ${ }^{2}$, Abdul Hakam ${ }^{3}$
}

\begin{abstract}
ABSTRAK
Sumber data yang didapat dari Badan Nasional Penanggulangan Bencana, dampak bencana gempa bumi 30 september 2009 di Sumatera Barat terdapat kerusakan fisik terparah akibat gempa pada tanggal tersebut, yaitu kerusakan bangunan terutama Bangunan Konstruksi Gedung. Amir Partowiyatmo \& Tri Harso Karyono (2008), dalam tema "Pesan Hari Standar Dunia Ke-39 : Intelligent dan Sustainnable Buildings", mengatakan bangunan yang rusak akibat bencana alam seperti gempa diantaranya disebabkan karena bangunan-bangunan tersebut belum menerapkan standar secara baik dan benar. Fakta dampak gempa besar di Kota Padang menunjukkan tidak semua bangunan konstruksi gedung yang runtuh, dampak gempa pada bangunan konstruksi sangat tergantung dengan kualitas konstruksi. Menurut James Lewis (2001), mengatakan ketahanan struktur pada bangunan yang dirancang, untuk gempa bumi tergantung pada nilai-nilai yang telah ditentukan.Menurut Drajat Hoedayanto (2009), mengatakan salah satu kerusakan dan keruntuhan bangunan sipil akibat gempa adalah karena kesadaran kebijakan yang ada karena kurangnya kesadaran dari pejabat terkait, Industri konstruksi, praktisi konstruksi dan ahli konstruksi.Hasil penelitian ini diharapkan bisa menjadi masukan untuk mengambil kebijakan-kebijakan konstruksi yang berpengaruh terhadap resiko dan menjadi masukan untuk membangun kamampuan kontraktor dalam berkonstribusi positif terhadap upaya-upaya dalam pengurangan resiko kegagalan bangunan. Penelitian ini menganalisis kontribusi kontraktor diteliti berdasarkan kategori pada pelaksanaan proyek konstruksi yaitu Sumber Daya Manusia, Metoda, Peralatan dan Material. Dimana ke empat katagori yang dimaksud yaitu sumber daya manusia dinilai berkontribusi (71,9\%), Metoda $(79,84 \%)$, Peralatan (70\%), Material (93,33\%), secara umum kontraktor telah berkontribusi terhadap pengurangan resiko kegagalan bangunan. Hasil uji statistik dipeoleh $\mathrm{p}-$ Value $=0,000$ pada masingmasing katogori dengan nilai OR sebesar sumber daya manusia $(\mathrm{OR}=1,923)$, metoda $(\mathrm{OR}=7,259)$, Peralatan $(1,709)$, dan material $(5,127)$. Ke empat katagori ini mempunyai hubungan keterkaitan terhadap pengurangan resiko kegagalan bangunan akibat gempa
\end{abstract}

Kata kunci : Kontribusi Kontraktor, pengurangan resiko, kegagalan bangunan

\section{PENDAHULUAN}

Kota Padang termasuk daerah rawan gempa. Menurut Pusat Vulkanologi dan Mitigasi Bencana Departemen Energi Sumatera Barat merupakan kawasan yang tergolong rawan terjadinya gempa bumi. Khususnya Kepulauan Mentawai dan pantai Barat Sumatera karena merupakan daerah yang paling dekat dengan pusat gempa bumi.

\footnotetext{
${ }^{1}$ Mahasiswa Pascasarjana Jurusan Teknik Sipil Fakultas Teknik Universitas Andalas, resi.elfitri@yahoo.com ${ }^{2}$ Staf Pengajar Jurusan Teknik Sipil Fakultas Teknik Universitas Andalas, akhmad.suraji@gmail.com

${ }^{3}$ Staf Pengajar Jurusan Teknik Sipil Fakultas Teknik Universitas Andalas, ahakam2008@yahoo.com
} 
LPPM Universitas Gajah Mada, mengatakan Sumber data yang didapat dari Badan Nasional Penanggulangan Bencana, dampak bencana gempa bumi 30 september 2009 di Sumatera Barat terdapat kerusakan fisik terparah akibat gempa pada tanggal tersebut, yaitu kerusakan bangunan terutama Bangunan Konstruksi Gedung.

Menurut Fauzi (2009), dari Pusat Gempa Nasional Badan Meteorologi dan Geofisika mengatakan kerugian akibat gempa bumi tidak langsung disebabkan oleh gempa bumi, namun disebabkan oleh kerentanan bangunan sehingga terjadi keruntuhan bangunan, kebakaran, tsunami dan tanah longsor. Faktor kerentanan bangunan, faktor kualitas tanah dan kualitas bangunan adalah faktor yang sangat menentukan untuk pengkajian resiko gempa bumi dimasa akan datang.

Amir Partowiyatmo \& Tri Harso Karyono (2008), dalam tema "Pesan Hari Standar Dunia Ke-39 : Intelligent dan Sustainnable Buildings", mengatakan bangunan yang rusak akibat bencana alam seperti gempa diantaranya disebabkan karena bangunan-bangunan tersebut belum menerapkan standar secara baik dan benar. Padahal kualitas konstruksi bangunan mempunyai arti penting. Selanjutnya TriHarso Karyo, sebagai Pakar Konstruksi menambahkan bahwa standar itu dinamis dengan artian berkembang mengikuti tunutunan kebutuhan manusia dan perkembangan ilmu pengetahuan dan teknologi

Dengan memahami hal tersebut, dapat dikembangkan kebijakan-kebijakan pro-aktif untuk membangun konstruksi agar mampu berperan positif dalam mengurangi resiko kegagalan banguanan dan berkontribusi terhadap seluruh upaya penanggulangan bencana khususnya di Kota Padang. Sehingga Dalam penelitian ini akan dilakukan Analisis "Kontribusi Kontraktor Terhadap Pengurangan Resiko Kegagalan Bangunan Akibat Gempa di Kota Padang”

\section{LANDASAN TEORI}

\subsection{Pelaku Proyek Konstruksi}

Dalam pelaksanaan proyek konstruksi terdapat pelaku dalam proyek tersebut, (Dipohusodo,1996) yaitu :

1. Pemilik Proyek atau Pemberi Tugas

Pemilik proyek adalah orang atau badan usaha yang memprakarsai,mendanai, dan mempunyai bangunan yang akan dilaksanakan dalamproses kegiatan suatu proyek konstruksi.

2. Kontraktor

Kontraktor adalah seseorang atau badan usaha yang ditugasi oleh pemilik proyek atau lembaga tertentu yang diberi wewenang secara profesional untuk bertanggung jawab dalam pelaksanaan proyek sesuai dengan ketentuan-ketentuan dan syarat-syarat yang telah ditentukan untuk mencapai tujuan dan sasaran yang telah disepakati.

3. Konsultan

Konsultan adalah perorangan atau perusahaan yang memiliki keahlian, kecakapan dan tersedia bagi yang memerlukan (klien) dengan imbalan sejumlah upah, dengan tugas memberikan nasehat, pengawasan, perencanaan, pelayanan atau pelatihan tentang hal yang berkaitan dengan bidang pengetahuan yang dikuasainya. (Soeharto,I. 1995)

\subsection{Kegagalan Konstruksi}

Undang - Undang 18 / 1999 tentang Jasa Konstruksi pasal 22 ayat g mengamanatkan bahwa ketentuan tentang tanggung jawab dalam hal salah satu pihak tidak melaksanakan kewajiban sebagaimana diperjanjikan harus dituangkan dalam kontrak kerja konstruksi, sedangkan dalam Peraturan Pemerintah Nomor: 29 Tahun 2000 tentang Penyelenggaraan Jasa Konstruksi pasal 31 menyatakan bahwa yang dimaksud dengan kegagalan konstruksi adalah keadaan hasil pekerjaan konstruksi yang tidak sesuai dengan

\section{0 | JURNAL REKAYASA SIPIL}


spesifikasi pekerjaan sebagaimana disepakati dalam kontrak kerja konstruksi baik sebagian maupun keseluruhan sebagai akibat dari kesalahan dari pengguna jasa atau penyedia jasa. Kegagalan konstruksi merupakan kegagalan yang bersifat teknis dan non teknis. Kegagalan ini dapat disebabkan karena kegagalan pada proses pengadaan barang/jasa, atau kegagalan saat proses pelaksanaan konstruksi.

\subsection{Kegagalan Bangunan}

Kegagalan bangunan dalam penyelenggaraan pekerjaan konstruksi harus dipahami pelaku jasa konstruksi, karena diyakini banyak pihak yang masih rancu dalam memahami kegagalan bangunan maupun kegagalan konstruksi, sebagaimana dinyatakan dalam UU 18/1999 pasal 1 ayat 6 bahwa yang dimaksud dengan kegagalan bangunan adalah keadaan bangunan yang setelah diserah-terimakan oleh penyedia jasa kepada pengguna jasa menjadi tidak berfungsi baik sebagian atau secara keseluruhan dan/atau tidak sesuai dengan ketentuan yang tercantum dalam kontrak kerja konstruksi atau pemanfaatannya yang menyimpang sebagai akibat kesalahan penyedia dan / atau pengguna jasa, sedangkan pengertian menurut PP 29/2000 pasal 34 bahwa kegagalan bangunan adalah keadaan bangunan yang tidak berfungsi, baik keseluruhan maupun sebagian dari segi teknis, manfaat, keselamatan dan kesehatan kerja dan atau keselamatan umum sebagai akibat kesalahan PenyediaJasa dan/atau Pengguna Jasa setelah penyerahan akhir Final Hand Over (FHO) pekerjaan konstruksi.

\subsection{Tanggung Jawab Kegagalan Konstruksi dan Kegagalan Bangunan}

Pada pasal 11 Undang-Undang RI No. 18 Tahun 1999 dijelaskan tentang tanggung jawab dari perencana konstruksi, pelaksana konstruksi dan pengawas konstruksi terhadap hasil pekerjaannya. Tanggung jawab tersebut dilandasi prinsip-prinsip keahlian sesuai kaidah keilmuan, kepatuhan, dan kejujuran intelektual dalam menjalankan profesinya dengan tetap mengutamakan kepentingan umum. Tanggung jawab dapat ditempuh melalui mekanisme pertanggungan sesuai dengan ketentuan peraturan perundang-undangan yang berlaku.

\subsection{Resiko}

Salim (1993) dalam Djojosoedarso (1999) mendefinisikan risiko sebagai ketidakpastian atas terjadinya suatu peristiwa. Pengertian lain menjelaskan bahwa risiko adalah kondisi dimana terdapat kemungkinan keuntungan / kerugian ekonomi atau finansial, kerusakan atau cedera fisik, keterlambatan, sebagai konsekuensi ketidakpastian selama dilaksanakannya suatu kegiatan (Cooper dan Chapman, 1993).

Pengertian risiko dalam konteks proyek dapat didefinisikan sebagai suatu penjabaran terhadap konsekuensi yang tidak menguntungkan, secara finansial maupun fisik, sebagai hasil dari keputusan yang diambil atau akibat kondisi lingkungan di lokasi suatu kegiatan. Jika dikaitkan dengan konsep peluang, "risiko" adalah peluang atau kans / chance terjadinya kondisi yang tidak diharapkan dengan semua konsekuensi yang mungkin muncul yang dapat menyebabkan keterlambatan atau kegagalan proyek (Gray dan Larson, 2000). Kerzner (2001) menjelaskan konsep risiko pada proyek sebagai "ukuran probabilitas dan konsekuensi dari tidak tercapainya suatu sasaran proyek yang telah ditentukan”.

\subsection{Gempa Bumi}

Gempa bumi adalah gejala alam, berupa sentakan alamiah yang terjadi di bumi, yang bersumber di dalam bumi dan merambat ke permukaan. Gempa adalah salah satu bencana alam

VOLUME 12 NO. 1, FEBRUARI 2016 | 51 
yang dapat diramalkan. Ada tiga kelompok pembagian gempa bumi yang lazim kita kenal. Pertama gempa tektonik, yaitu yang berkaitan erat dengan pembentukan patahan (fault), sebagai akibat langsung dari tumbukan antar lempeng pembentuk kulit bumi. Gempa ini merupakan gempa yang umumnya berkekuatan lebih dari 5 skala Richter. Gempa vulkanik, yaitu gempa berkaitan dengan aktivitas gunung api. Gempa ini merupakan gempa mikro sampai menengah, gempa ini umumnya berkekuatan kurang dari 4 skala Richter. Ketiga, terban yang muncul akibat longsoran / terban dan merupakan gempa kecil. Kekuatan gempa mungkin sangat kecil sehingga yang muncul tidak terasa, berupa tremor dan hanya terdeteksi oleh seismograf.

\section{METODOLOGI}

Desain penelitian ini untuk memberikan gambaran singkat mengenai tahapan penelitian dari tahap awal hingga akhir, menjelaskan korelasi antar variable yang akan diteliti. Kerangka Penelitian ini dituangkan dalam bagan alir seperti gambar dibawah ini.

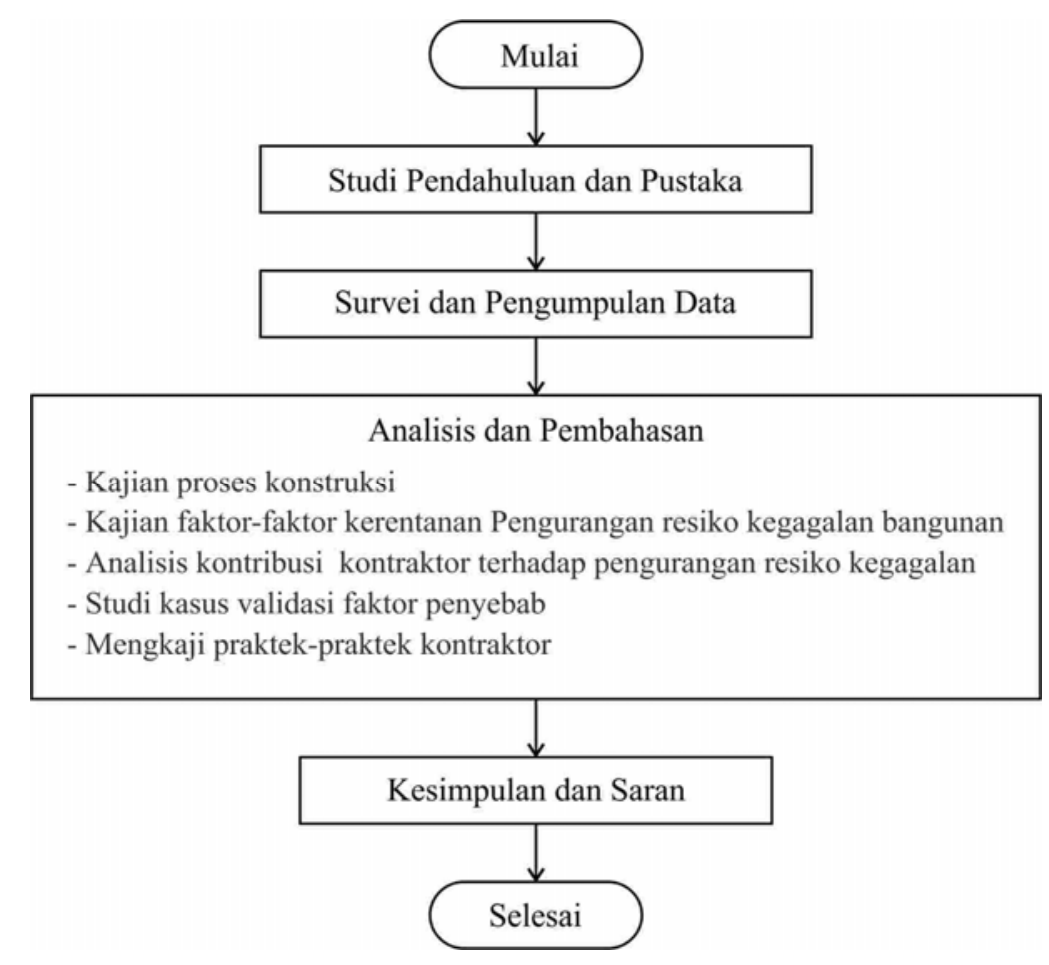

Gambar 1. Diagram Alir Metoda Penelitian

\section{HASIL PENELITIAN DAN PEMBAHASAN}

\subsection{Analisis Kontribusi Kontraktor}

Kontribusi kontraktor diteliti berdasarkan kategori pada pelaksanaan proyek konstruksi yaitu Sumber Daya Manusia, Metoda, Peralatan dan Material.

KATEGORI I : SUMBER DAYA MANUSIA (SDM)

52 | JURNAL REKAYASA SIPIL 
Tabel 4.1.1 Kontribusi Kontraktor pada Kategori Sumber Daya Manusia (SDM)

\begin{tabular}{|c|c|c|c|c|}
\hline \multirow[b]{2}{*}{$\begin{array}{l}\text { KATEGORI } \\
\text { I }\end{array}$} & \multirow[b]{2}{*}{ NO } & \multirow[b]{2}{*}{$\begin{array}{c}\text { KONTRIBUSI KONTRAKTOR TERHADAP } \\
\text { PENGURANGAN RESIKO KEGAGALAN } \\
\text { BANGUNAN }\end{array}$} & \multicolumn{2}{|c|}{ Tingkat Kontribusi } \\
\hline & & & $\begin{array}{l}\text { Tidak } \\
\text { Berkontri- } \\
\text { busi } \\
(\%)\end{array}$ & $\begin{array}{l}\text { Berkontri- } \\
\quad \text { busi } \\
(\%)\end{array}$ \\
\hline \multirow{7}{*}{$\begin{array}{l}\text { SUMBER } \\
\text { DAYA } \\
\text { MANUSIA } \\
\text { (SDM) }\end{array}$} & 1 & $\begin{array}{l}\text { Pelaksana konstruksi harus memiliki sertifikat } \\
\text { keterampilan kerja dan sertifikat keahlian kerja. }\end{array}$ & 13.33 & 86.67 \\
\hline & 2 & $\begin{array}{l}\text { Kontraktor mempersiapkan Tenaga kerja pada } \\
\text { pelaksana konstruksi yang memiliki sertifikat } \\
\text { keterampilan dan keahlian kerja. }\end{array}$ & 50.00 & 50.00 \\
\hline & 3 & $\begin{array}{l}\text { Kontraktor Menggunakan tenaga engineer sipil } \\
\text { dan pelaksana lapangan yang berpengalaman }\end{array}$ & 6.67 & 93.33 \\
\hline & 4 & Kontraktor lebih teliti pada pemilihan personil & 30.00 & 70.00 \\
\hline & 5 & $\begin{array}{l}\text { Kontraktor harus tepat dalam memilih supplier } \\
\text { dan subkontraktor }\end{array}$ & 26.67 & 73.33 \\
\hline & 6 & $\begin{array}{l}\text { Kontraktor memberikan upah tenaga kerja sesuai } \\
\text { standar }\end{array}$ & 6.67 & 93.33 \\
\hline & 7 & Kontraktor melakukan pelatihan untuk pekerja & 63.33 & 36.67 \\
\hline & & RATA - RATA & 28.10 & 71.90 \\
\hline
\end{tabular}

\section{KATEGORI II : METODA}

Tabel 4.1.2 Kontribusi Kontraktor pada Katergori Metoda

\begin{tabular}{|c|c|c|c|c|}
\hline \multirow[b]{2}{*}{$\begin{array}{c}\text { KATEGORI } \\
\text { II }\end{array}$} & \multirow[b]{2}{*}{ NO } & \multirow[b]{2}{*}{$\begin{array}{c}\text { KONTRIBUSI KONTRAKTOR TERHADAP } \\
\text { PENGURANGAN RESIKO KEGAGALAN } \\
\text { BANGUNAN }\end{array}$} & \multicolumn{2}{|c|}{ Tingkat Kontribusi } \\
\hline & & & $\begin{array}{l}\text { Tidak } \\
\text { Berkontri- } \\
\text { busi } \\
\text { (\%) }\end{array}$ & $\begin{array}{l}\text { Berkontri- } \\
\text { busi } \\
(\%)\end{array}$ \\
\hline \multirow[t]{9}{*}{ METODA } & 1 & $\begin{array}{l}\text { Kontraktor memiliki pengalaman pembangunan } \\
\text { konstruksi sejenis }\end{array}$ & 10.00 & 90.00 \\
\hline & 2 & $\begin{array}{l}\text { Kontraktor melakukan pekerjaan sesuai kontrak } \\
\text { kerja konstruksi }\end{array}$ & 13.33 & 86.67 \\
\hline & 3 & $\begin{array}{l}\text { Kontraktor melakukan konsultasi atau verifikasi } \\
\text { dengan perencana terkait dengan dokumen } \\
\text { perencanaan }\end{array}$ & 33.33 & 66.67 \\
\hline & 4 & $\begin{array}{l}\text { Kontraktor melakukan perubahan spesifikasi } \\
\text { (change order) sesuai kaidahnya }\end{array}$ & 46.67 & 53.33 \\
\hline & 5 & $\begin{array}{l}\text { Kontraktor Melaksanakan pembangunan sesuai } \\
\text { dengan perencanaan yang disusun konsultan } \\
\text { perencana }\end{array}$ & 13.33 & 86.67 \\
\hline & 6 & $\begin{array}{l}\text { Kontraktor Melaksanakan tolak ukur kegagalan } \\
\text { bangunan seperti : Perencanaan, Sifat bahan } \\
\text { bangunan, Pengujian bahan dan bangunan } \\
\text { konstruksi dan pelaksanaan dan pengawasan }\end{array}$ & 46.67 & 53.33 \\
\hline & 7 & $\begin{array}{l}\text { Kontraktor menginformasikan kejanggalan } \\
\text { perencanaan yang dapat merugikan pemilik } \\
\text { proyek. }\end{array}$ & 30.00 & 70.00 \\
\hline & 8 & $\begin{array}{l}\text { Kontraktor memperhatikan masalah lingkungan } \\
\text { dalam proses konstruksi }\end{array}$ & 23.33 & 76.67 \\
\hline & 9 & $\begin{array}{l}\text { Kontraktor memiliki dan melaksanakan sistem } \\
\text { manajemen mutu (iso) }\end{array}$ & 40.00 & 60.00 \\
\hline
\end{tabular}


KONTRIBUSI KONTRAKTOR TERHADAP PENGURANGAN RESIKO KEGAGALAN BANGUNAN AKIBAT GEMPA DI KOTA PADANG

\begin{tabular}{|c|c|c|c|}
\hline 10 & $\begin{array}{l}\text { Kontraktor melakukan pelaksanaan pekerjaan } \\
\text { sesuai Schedule yang tepat }\end{array}$ & 26.67 & 73.33 \\
\hline 11 & $\begin{array}{l}\text { Kontraktor melakukan pengawasan secara tertib } \\
\text { dan koordinasi kepada owner }\end{array}$ & 26.67 & 73.33 \\
\hline 12 & $\begin{array}{l}\text { Kontraktor jika menemukan penyimpangan dalam } \\
\text { pembangunan, melaporkan } \\
\text { penyimpangan kepada owner }\end{array}$ & 23.33 & 76.67 \\
\hline 13 & $\begin{array}{l}\text { Kontraktor membuat laporan rekomendasi tentang } \\
\text { hasil pembangunan gedung tersebut }\end{array}$ & 13.33 & 86.67 \\
\hline 14 & $\begin{array}{l}\text { Kontraktor Lebih cermat dan teliti dalam } \\
\text { melaksanakan fondasi untuk Struktur tahan gempa }\end{array}$ & 16.67 & 83.33 \\
\hline 15 & $\begin{array}{l}\text { Kontraktor memperhatikan struktur pemikul beban } \\
\text { gempa, kuat tekan beton minimum }=20 \mathrm{MPa} \\
(\mathrm{K} \square 250) \text {; }\end{array}$ & 13.33 & 86.67 \\
\hline 16 & Kontraktor menggunakan Baja tulangan ulir & 13.33 & 86.67 \\
\hline 17 & $\begin{array}{l}\text { Kontraktor memperhatikan sistem struktur yang } \\
\text { digunakan disesuaikan dengan tingkat kerawanan } \\
\text { dan daerah potensi gempa }\end{array}$ & 3.33 & 96.67 \\
\hline 18 & $\begin{array}{lccr}\text { Kontraktor } & \text { memahami } & \text { aturan } & \text { detailing } \\
\text { (penulangan) } & \text { dibedakan } \\
\text { berawanan terhadap gempa. } & & & \\
\text { berdasarkan } & & \\
\text { tingkat }\end{array}$ & 13.33 & 86.67 \\
\hline 19 & $\begin{array}{l}\text { Kontraktor memahami Pelaksanaan pekerjaan } \\
\text { sambungan balok dan kolom harus menjamin } \\
\text { perilaku kolom kuat-balok lemah (strong columb- } \\
\text { weak beam) }\end{array}$ & 0.00 & 100.00 \\
\hline 20 & $\begin{array}{l}\text { Kontraktor memahami pencegahan pelaksanaan } \\
\text { pekerjaan kolom Pendek (accidental ) dan semua } \\
\text { tulangan kolom terjangkar dalam fondasi }\end{array}$ & 10.00 & 90.00 \\
\hline 21 & $\begin{array}{l}\text { Kontraktor memahami Pelat tanpa di dukung oleh } \\
\text { balok (Flat slab ) dilarang sebagai Sistem Pemikul } \\
\text { Beban Lateral di wilayah gempa resiko tinggi }\end{array}$ & 10.00 & 90.00 \\
\hline 22 & $\begin{array}{l}\text { Kontraktor tidak menggunakan komponen struktur } \\
\text { prategang sebagai Sistem Pemikul Beban Lateral }\end{array}$ & 26.67 & 73.33 \\
\hline 23 & $\begin{array}{l}\text { Kontraktor memperhatikan Panjang sambungan } \\
\text { lewatan tulangan kolom } 50 \mathrm{~d} \text { dan lokasinya harus } \\
\pm \text { tengah tinggi kolom Sambungan lewatan } \\
\text { tulangan balok harus jauh dari Sendi Plastis (SP) }\end{array}$ & 16.67 & 83.33 \\
\hline & RATA - RATA & 20.43 & 79.84 \\
\hline
\end{tabular}

\section{KATEGORI III : PERALATAN}

Tabel 4.1.3 Kontribusi Kontraktor pada kategori Peralatan

\begin{tabular}{|c|c|c|c|c|}
\hline \multirow[b]{2}{*}{$\begin{array}{c}\text { KATEGORI } \\
\text { III }\end{array}$} & \multirow[b]{2}{*}{ NO } & \multirow[b]{2}{*}{$\begin{array}{c}\text { KONTRIBUSI KONTRAKTOR TERHADAP } \\
\text { PENGURANGAN RESIKO KEGAGALAN } \\
\text { BANGUNAN }\end{array}$} & \multicolumn{2}{|c|}{ Tingkat Kontribusi } \\
\hline & & & $\begin{array}{l}\text { Tidak } \\
\text { Berkontri- } \\
\text { busi } \\
(\%)\end{array}$ & $\begin{array}{l}\text { Berkontri- } \\
\quad \text { busi } \\
\quad(\%)\end{array}$ \\
\hline \multirow[t]{2}{*}{ PERALATAN } & 1 & Kontraktor menggunakan peralatan alat baru & 33.33 & 66.67 \\
\hline & 2 & $\begin{array}{l}\text { Kontraktor mempergunakan Jumlah alat yang } \\
\text { memadai }\end{array}$ & 26.67 & 73.33 \\
\hline \multicolumn{3}{|r|}{ RATA - RATA } & 30 & 70 \\
\hline
\end{tabular}


KATEGORI IV : MATERIAL

Tabel 4.1.4 Kontribusi Kontraktor pada kategori Material

\begin{tabular}{|c|c|c|c|c|}
\hline \multirow[b]{2}{*}{$\begin{array}{l}\text { KATEGORI } \\
\text { IV }\end{array}$} & \multirow[b]{2}{*}{ NO } & \multirow[b]{2}{*}{$\begin{array}{c}\text { KONTRIBUSI KONTRAKTOR } \\
\text { TERHADAP PENGURANGAN RESIKO } \\
\text { KEGAGALAN BANGUNAN }\end{array}$} & \multicolumn{2}{|c|}{ Tingkat Kontribusi } \\
\hline & & & $\begin{array}{c}\text { Tidak } \\
\text { Berkontri- } \\
\text { busi } \\
(\%)\end{array}$ & $\begin{array}{l}\text { Berkontri- } \\
\text { busi } \\
\text { (\%) }\end{array}$ \\
\hline MATERIAL & 1 & $\begin{array}{l}\text { Kontraktor Menggunakan material } \\
\text { Standar Nasional }\end{array}$ & 6.67 & 93.33 \\
\hline \multicolumn{3}{|r|}{ RATA - RATA } & 6.67 & 93.33 \\
\hline
\end{tabular}

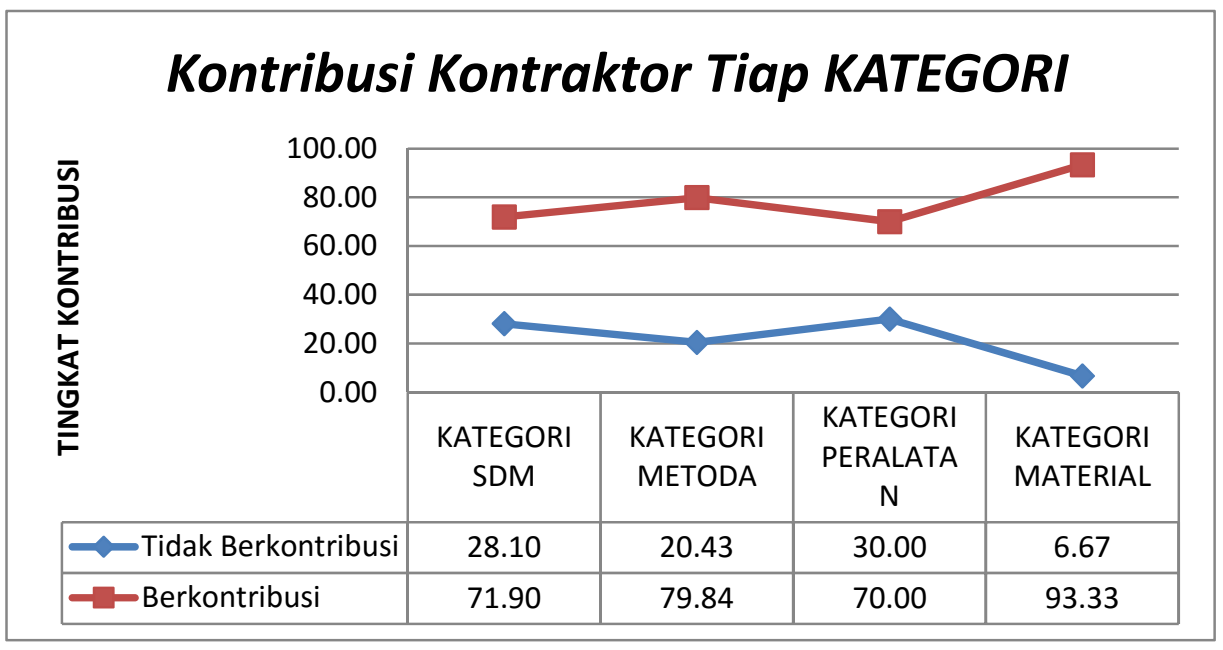

Grafik 1 Kontribusi kontraktor pada Kategori Sumber daya Manusia, Metoda, Peralatan dan Material

4.2 Hubungan Sumber daya Manusia, Metoda Pelaksanaan, Peralatan dan Material terhadap pengurangan resiko kegagalan bangunan akibat gempa

Analisis Korelasi Variabel Kuantitatif, Kegagalan Bangunan digunakan untuk menguji seberapa kuat hubungan empat variabel kuantitatif. Hasil Uji korelasi selengkapnya seperti disajikan pada Tabel berikut.

Tabel 4.2.1 Hubungan Sumber daya Manusia terhadap Pengurangan Resiko Kegagalan Bangunan

\begin{tabular}{|c|c|c|c|c|c|c|c|c|}
\hline \multirow[t]{3}{*}{ SDM } & \multicolumn{4}{|c|}{ Kegagalan Konstruksi } & \multicolumn{2}{|c|}{ Jumlah } & \multirow[t]{3}{*}{ OR 95\% CI } & \multirow[t]{3}{*}{ P - Value } \\
\hline & \multicolumn{2}{|c|}{ Beresiko } & \multicolumn{2}{|c|}{ Tidak Beresiko } & & & & \\
\hline & $\mathrm{Jml}$ & $\%$ & Jml & $\%$ & Jml & $\%$ & & \\
\hline Tidak Penting & 9 & 52,9 & 5 & 38,5 & 14 & 46,7 & 1,923 & 0,000 \\
\hline Penting & 8 & 47,1 & 8 & 61,5 & 16 & 53,3 & & \\
\hline Total & 17 & 100 & 13 & 100 & 30 & 100 & & \\
\hline
\end{tabular}

Hubungan antara Sumber Daya Manusia terhadap Pengurangan Resiko Kegagagalan Bangunan menunjukkan bahwa dari hasil uji statistik diperoleh nilai $\mathrm{p}=0,00$ ( $\mathrm{p}$-value $<0,05$ ). Dengan demikian hal ini dapat diartikan ada hubungan yang bermakna antara sumber daya 
manusia terhadap Pengurangan Resiko Kegagagalan Bangunan dengan nilai OR $=1,923$. Artinya Metoda pada Pelaksanaan Konstruksi mempunyai hubungan, yaitu sebesar 1,923 kali berkontribusi terhadap Pengurangan Resiko Kegagalan Bangunan.

Faktanya dapat dilihat kontribusi kontraktor terhadap pengurangan resiko kegagalan bangunan akibat gempa sudah lebih baik pada kategori sumber daya manusia (SDM) yaitu $53,3 \%$.

Tabel 4.2.1 Hubungan Metoda Pelaksanaan Konstruksi terhadap Pengurangan Resiko Kegagalan Bangunan

\begin{tabular}{|ccccccccc|}
\hline SDM & \multicolumn{1}{c}{ Kegagalan Konstruksi } & Jumlah & OR 95\% CI & P - Value \\
\hline & Beresiko & \multicolumn{2}{c|}{ Tidak Beresiko } & & & & \\
& Jml & $\%$ & Jml & $\%$ & Jml & $\%$ & & \\
\hline Tidak Penting & 12 & 70,6 & 4 & 30,8 & 16 & 53,3 & 7,259 & 0,000 \\
Penting & 5 & 29,4 & 9 & 69,2 & 14 & 46,7 & & \\
\hline \hline Total & $\mathbf{1 7}$ & $\mathbf{1 0 0}$ & $\mathbf{1 3}$ & $\mathbf{1 0 0}$ & $\mathbf{3 0}$ & $\mathbf{1 0 0}$ & & \\
\hline
\end{tabular}

Hubungan antara Metoda terhadap Pengurangan Resiko Kegagagalan Bangunan menunjukkan bahwa dari hasil uji statistik diperoleh nilai $p=0,00$ ( $p$-value $<0,05)$. Dengan demikian hal ini dapat diartikan ada hubungan yang bermakna antara Metode pelaksanaan konstruksi terhadap Pengurangan Resiko Kegagagalan Bangunan dengan nilai OR = 7,259. Artinya Metoda pada Pelaksanaan Konstruksi mempunyai hubungan, yaitu sebesar 7,259 kali berkontribusi terhadap Pengurangan Resiko Kegagalan Bangunan.

Tabel 4.2.2 Hubungan Peralatan pada Pelaksanaan Konstruksi terhadap Pengurangan Resiko Kegagalan Bangunan

\begin{tabular}{|c|c|c|c|c|c|c|c|c|}
\hline \multirow[t]{3}{*}{ SDM } & \multicolumn{4}{|c|}{ Kegagalan Konstruksi } & \multicolumn{2}{|c|}{ Jumlah } & \multirow[t]{3}{*}{ OR 95\% CI } & \multirow[t]{3}{*}{ P - Value } \\
\hline & \multicolumn{2}{|c|}{ Beresiko } & \multicolumn{2}{|c|}{ Tidak Beresiko } & \multirow[b]{2}{*}{$\mathrm{Jml}$} & \multirow[b]{2}{*}{$\%$} & & \\
\hline & Jml & $\%$ & Jml & $\%$ & & & & \\
\hline Tidak Penting & 7 & 41,2 & 5 & 38,5 & 12 & 40 & 1,709 & 0,000 \\
\hline Penting & 10 & 58,8 & 8 & 61,5 & 18 & 60 & & \\
\hline Total & 17 & 100 & 13 & 100 & 30 & $\overline{100}$ & & \\
\hline
\end{tabular}

Hubungan antara Kategori Peralatan terhadap Pengurangan Resiko Kegagagalan Bangunan menunjukkan bahwa dari hasil uji statistik diperoleh nilai $\mathrm{p}=0,00$ ( $\mathrm{p}$-value $<0,05)$. Dengan demikian hal ini dapat diartikan ada hubungan yang bermakna antara Metode pelaksanaan konstruksi terhadap Pengurangan Resiko Kegagagalan Bangunan dengan nilai OR $=1,709$. Artinya Peralatan pada Pelaksanaan Konstruksi mempunyai hubungan, yaitu sebesar 1,709 kali berkontribusi terhadap Pengurangan Resiko Kegagalan Bangunan.

Tabel 4.2.3 Hubungan Material terhadap Pengurangan Resiko Kegagalan Bangunan

\begin{tabular}{|c|c|c|c|c|c|c|c|c|}
\hline \multirow[t]{3}{*}{ SDM } & \multicolumn{4}{|c|}{ Kegagalan Konstruksi } & \multicolumn{2}{|c|}{ Jumlah } & \multirow[t]{3}{*}{ OR 95\% CI } & \multirow[t]{3}{*}{ P - Value } \\
\hline & \multicolumn{2}{|c|}{ Beresiko } & \multicolumn{2}{|c|}{ Tidak Beresiko } & & & & \\
\hline & Jml & $\%$ & $\mathrm{Jml}$ & $\%$ & $\mathrm{Jml}$ & $\%$ & & \\
\hline Tidak Penting & 11 & 64,7 & 4 & 30,8 & 15 & 50,0 & 5,127 & 0,000 \\
\hline Penting & 6 & 35,3 & 9 & 69,2 & 15 & 50,0 & & \\
\hline Total & 17 & 100 & 13 & 100 & 30 & 100 & & \\
\hline
\end{tabular}

Hubungan antara Kategori Material terhadap Pengurangan Resiko Kegagagalan Bangunan menunjukkan bahwa dari hasil uji statistik diperoleh nilai $p=0,00$ ( $p$-value $<0,05$ ). Dengan demikian hal ini dapat diartikan ada hubungan yang bermakna antara Metode pelaksanaan konstruksi terhadap Pengurangan Resiko Kegagagalan Bangunan dengan nilai OR

\section{6 | JURNAL REKAYASA SIPIL}


$=5,127$. Artinya Metoda pada Pelaksanaan Konstruksi mempunyai hubungan, yaitu sebesar 5,127 kali berkontribusi terhadap Pengurangan Resiko Kegagalan Bangunan.

\section{KESIMPULAN}

Berdasarkan hasil penelitian yang telah dilakukan, maka dapat diambil beberapa kesimpulan sebagai berikut :

1. Tingkat persentase pada kategori sumberdaya manusia $(53,3 \%)$, metoda pelaksanaan $(46,7)$, Peralatan $(60 \%)$ dan Material (50\%), secara umum kontraktor telah memberikan nilai positif terhadap kuisioner, berarti ada kemauan untuk berperan/berkontribusi terhadap pengurangan kegagalan bangunan akibat gempa di kota padang.

2. Hubungan kategori sumberdaya manusia, metoda pelaksanaan, Peralatan dan Material terhadap pengurangan kegagalan bangunan akibat gempa di kota padang, hasil uji stattistik diperoleh nilai $\mathrm{p}=0,00$ ( $\mathrm{p}$-value $<0,05)$ keempat kategori mempunyai hubungan terhadap Pengurangan Resiko Kegagagalan Bangunan.

\section{DAFTAR KEPUSTAKAAN}

Abrar Husen, (2008) Manajemen Proyek, Perencanaan, Penjadwalan dan Pengendalian Proyek, Yogyakarta : Penerbit Andi

Ahmad Agus, (2006) Pengaruh tingkat pemahaman manajemen Risiko oleh manajer konstruksi FT-UI

Ahmad Muktaf, (2008). Manajemen Risiko Bencana Gempa Bumi (Studi Kasus Gempa Bumi Yogyakarta 27 Mei 2006). Yokyakarta : Seminar Nasional IV Sdm Teknologi Nuklir, 2005-2006 Agustus 2008

Ahmad Waryanto, (1998) Construction Planning and Scheduling Sebuah Pengantar Program Pasca Sarjana-Bidang Ilmu Teknik Sipil, Universitas Indonesia.

Ahuja, Hira., Techniqyues in Planning and Controlling Construktion Project, Jhon Wiley \& Sons, New York, 1981

Allan Asworth, 1994, Cost Study of Buildings, Terjemahan oleh Laurentius Wahyudi, Gramedia Jakarta.

Cooper, D. dan Chapman, C. (1993). Risk Analysis For Large Project. First Edition. John Wiley \& Sons Ltd., Norwich.

Darmawi, H. (1990) Manajemen Risiko. Edisi Pertama. Penerbit Bumi Aksara,Jakarta

Djojosoedarso, Soeisno, (2003), Prinsip-Prinsip Manajemen Risiko Dan Asuransi, Salemba Empat, Jakarta.

Donald S. Barrie, Boyd. C. Paulson, Jr., 1954, Profesional Construction Management (Diterjemahkan oleh Susinarto, Erlangga Jakarta.

H. Murray Hohns, 1979, Preventing and Solving Construction Contract Disputes, Van Mostrand Reinhold Company, New York.

Harrison, F.L., Advanced Project Management 2nd Edition, Gower Publishing Company Limited, England, 1985

Idzurnida Ismael, (2012) “Analisa Faktor Resiko Pembangunan Gedung Non Perumahan Terhadap Kualitas Proyek Konstruksi di Kota Padang Sumatera Barat” Jurnal Momentum

Iman Soeharto, 1995, Manajemen Proyek dari Konseptual sampai Operasional, Erlangga, Jakarta.

Ishikawa, Kaoru, Guide to Quality Control, Asian Productivity Organization, UNIPUB, 1976

James W. Cortada, 1996, Total Quality Management (Terjemahan oleh Eko Suwarsi), Andi Offset, Yogyakarta.

Kezner, Harold (2001) Project Management. Seventh Edition. John Wiley \& Sons, Inc., New York.

VOLUME 12 NO. 1, FEBRUARI 2016 | 57 
M. Pete Spinner, 1997, Project Management-Principles and Practices, Prentice Hall-Inc, New Jersey.

Mason, R.D \& Douglas A. Lind. 1999. Teknik Statistik Untuk Bisnis dan Ekonomi, Jilid 2. Jakarta: Penerbit Erlangga.

R.L. Peurifoy and G.D. Oberlender, 1989, Estimating Constructions Costs, Mc Graw-Hill Company, New York.

Ritchie, B. and Marshall, D. (1993) Business Risk Management. First Edition. Chapman \& London.

Umar, H, (2001), Riset Pemasaran Dan Perilaku Konsumen, Edisi pertama, PT. Gramedia Pustaka Utama, Jakarta.

Usman, H. \& R. Purnomo Setiady Akbar. 2000. Pengantar Statistika. Jakarta: Bumi Aksara

Webb, Alan (1994) Managing Innovative Projects. First Edition. Chapman \& Hall, London 